\title{
Paracetamol for Patent Ductus Arteriosus Closure: High Osmolality of Enteral Form and Spontaneous Intestinal Perforation
}

\author{
Amrit Tuteja $^{1}$ - Femitha Pournami ${ }^{1}$ (D) Arif Abdulsalam Kolisambeevi ${ }^{1} \cdot$ Anand Nandakumar $^{1} \cdot$ Jyothi Prabhakar $^{1}$. \\ Naveen Jain ${ }^{1}$
}

Received: 19 May 2020 / Accepted: 7 July 2020 / Published online: 16 July 2020

(C) Dr. K C Chaudhuri Foundation 2020

To the Editor: Efficacy of oral and intravenous paracetamol for hemodynamically significant patent ductus arteriosus (hsPDA) is comparable to older agents; with lesser complications [1]. It becomes imperative for clinicians to be aware of problems that may be associated with it. We report a case of intestinal perforation after oral paracetamol for hsPDA. We believe that the osmolality of the formulation may be partially responsible.

Baby $\mathrm{S}$ was delivered at 28 wk with $850 \mathrm{~g}$ weight for abnormal umbilical artery dopplers. Parenteral nutrition was initiated and standard feed regimens were followed (mother's own milk). On day 6 she reached $100 \mathrm{ml} / \mathrm{kg} / \mathrm{d}$ of feeds. On day 7 , echo confirmed the presence of hsPDA. Standard recommended dose of oral paracetamol $15 \mathrm{mg} / \mathrm{kg} /$ dose (Calpol drops $100 \mathrm{mg} / \mathrm{ml}$, Glaxosmithkline) every $8 \mathrm{~h}$ for $3 \mathrm{~d}$ was administered by orogastric tube with the scheduled feeds. Around $36 \mathrm{~h}$ later, she developed abdominal distension and bilious aspirates. Inotropes were required. X-ray evidence of free air in the peritoneum required a bedside peritoneal drain insertion. Laporotomy done $48 \mathrm{~h}$ later revealed multiple large perforations in the descending colon, with rest of the bowel uncompromised. Colostomy was performed. Subsequently, feeds could be escalated up to $90 \mathrm{ml} / \mathrm{kg} / \mathrm{d}$. Alas on day 26 of life, she developed features of sepsis. Blood culture was reported positive for Serratia marsescens. Inspite of appropriate antibiotics and intensive care, baby succumbed on day 28 of life.

Safety studies of paracetamol for hsPDA have focused on reporting the expected hepatoxicity, with elevated bilirubin and hepatic enzymes typically occurring 3 to $5 \mathrm{~d}$ into the course [2]. Indian studies have reported no serious adverse events [3]. A recent study has noted $20 \%$ incidence of

Femitha Pournami

femi_shifas@yahoo.com

1 Department of Neonatology, Kerala Institute of Medical Sciences, Trivandrum 695029 India spontaneous intestinal perforation (SIP). It is difficult to evaluate the relationship between paracetamol and necrotising enterocolitis or SIP [4].

Drug osmolality is an often overlooked pharmacokinetic aspect, when therapy is instituted enterally. A literature review of the topic revealed shocking revelations of extremely high osmolality of several drugs that are quite often used in neonatal practice. Osmolality of $330-350 \mathrm{mOsm} / \mathrm{kg} \mathrm{H} \mathrm{H}_{2} \mathrm{O}$ is considered appropriate for enteral administration. Oral paracetamol was found to have osmolality above $7000 \mathrm{mosm} / \mathrm{kg} \mathrm{H}_{2} \mathrm{O}$ [5].

Further use of these medications may need attention to formulations suitable for use in preterm neonates.

\section{Compliance with Ethical Standards}

Conflict of Interest None.

\section{References}

1. Ohlsson A, Shah PS. Paracetamol (acetaminophen) for patent ductus arteriosus in preterm or low birth weight infants. Cochrane Database Syst Rev. 2020;1:CD010061.

2. Terrin G, Conte F, Oncel MY, et al. Paracetamol for the treatment of patent ductus arteriosus in preterm neonate: a systematic review and meta analysis. Arch Dis Child Fetal Neonatal Ed. 2016;101:F12736.

3. Dash SK, Kabra NS, Avasthi BS, Sharam SR, Padhi P, Ahmed J. Enteral paracetamol or intravenous indomethacin for closure of patent ductus arteriosus in preterm neonates: a randomized controlled trial. Indian Pediatr. 2015;52:573-8.

4. Luecke CM, Liviskie CJ, Zeller BN, Vesoulis ZA, McPherson C. Acetaminophen for patent ductus arteriosus in extremely low-birthweight neonates. J Pediatr Pharmacol Ther. 2017;22:461-6.

5. Polo AF, Poy M, Bautista SC, Oliveras M, Salinas FC, Albert EH. Osmolality of oral liquid dosage forms to be administered to newborns in a hospital. Farm Hosp. 2007;31:311-4.

Publisher's Note Springer Nature remains neutral with regard to jurisdictional claims in published maps and institutional affiliations. 